\title{
IN VIVO STUDIES ON FLEXION AND EXTENSION OF THE LUMBAR SPINE AFTER STABILISATION WITH A NON-FUSION PEDICLE SCREW SYSTEM
}

\author{
ESTUDOS IN VIVO SOBRE FLEXÃO E EXTENSÃO DA COLUNA LOMBAR APÓS ESTABILIZAÇÃO \\ COM SISTEMA DE PARAFUSO PEDICULAR COM TÉCNICA DE NÃO-FUSÃO
}

\author{
ESTUDIOS IN VIVO DE FLEXIÓN Y EXTENSIÓN DE LA COLUMNA LUMBAR DESPUÉS DE \\ ESTABILIZACIÓN CON UN SISTEMA DE TORNILLO DE PEDÍCULO DE NO FUSIÓN
}

Jörg Rainer Klauß ${ }^{1}$, Richter MJ², Hendrik Bergert ${ }^{3}$, Rainer Braunschweig ${ }^{3}$, Klaus Roehl ${ }^{1}$

\begin{abstract}
Objective: The aim was to determine in vivo whether pre-operative mobility of the lumbar spine (overall and segmental) is retained after surgical intervention. Methods: Functional imaging of the lumbar spine was performed in flexion and extension, using a lateral projection under standardised conditions. This allowed assessment of the overall mobility, mobility of the instrumented mobile segments and the disc height of the adjacent cranial segment (intervertebral space; IVS) before and after surgical intervention. Images were evaluated independently by a radiologist and an orthopaedic surgeon. A comparative analysis of preoperative and postoperative functional images was carried out with the aid of a computer and appropriate software (ACES) for further assessment of the extent to which the range of movement was retained. The Oswestry Disability Index (ODI, quality of life assessment) and the visual analogue scale (VAS, pain assessment) were used as clinical criteria and compared pre-and postoperatively. The mean follow-up (FU) intervals were 13.5 days (FU 1) and 19 months (FU 2). Results: Radiological results showed that the overall mobility of the lumbar spine (L1 to S1) decreased on average by one third of the flexion/ extension range, from $25.0^{\circ}$ preoperatively to $17.6^{\circ}$ postoperatively. The segmental mobility of the monosegmental stabilisation decreased on average from $3.7^{\circ}$ to $2.3^{\circ}$. The caudal segments of the bisegmental dynamic stabilisation retained their preoperative movement range of $2.6^{\circ}$, with a postoperative range of $2.4^{\circ}$. The IVS did not change. The ODI improved postoperatively from 59 (preoperative) to $39 / 41$ (FU1/ FU2) points, while the VAS (during movement) improved from 7.6 (pre-op) to 4.4/4.5 (FU1/FU2). Computer-assisted analysis showed that small and functionally insignificant micro-motion of $0.4^{\circ}$ (error $0.12 \%$ ) remained in the stabilised and unfused mobile segment. Conclusion: Comparison of preoperative and postoperative measurements showed that overall mobility and segmental micro-motion were retained after non-fusion stabilisation of the lumbar spine with monosegmental and bisegmental instrumentation. The adjacent cranial segment (IVS) did not collapse. Activity levels (ODI) and pain symptoms (VAS) of the patients showed significant improvement at follow-up, comparable to that reported in the literature for conventional rigid spinal fusions.
\end{abstract}

Keywords: Radiography; Internal fixators; Spine; Bone screws.

\section{RESUMO}

Objetivo: O objetivo foi determinar in vivo se a mobilidade pré-operatória da coluna lombar (geral e segmentar) é mantida depois da intervenção cirúrgica. Métodos: Foram realizadas imagens funcionais da coluna lombar em flexão e extensão, usando projeção lateral em condições padronizadas. Isso permitiu a avaliação da mobilidade geral, da mobilidade dos segmentos móveis instrumentados e da altura do disco do segmento rostral adjacente (espaço intervertebral; IVS) antes e depois da intervenção cirúrgica. As imagens foram analisadas independentemente por um radiologista e por um cirurgião ortopedista. Realizou-se análise comparativa das imagens funcionais pré e pós-operatórias com o auxílio de computador e de software apropriado (ACES) para avaliar mais detalhadamente a extensão em que a amplitude de movimento foi mantida. O Oswestry Disability Index (ODI, avaliação da qualidade de vida) e a escala visual analógica (VAS, avaliação da dor) foram usadas como critérios clínicos e comparadas no pré e pós-operatório. Os intervalos médios de acompanhamento (FU, de follow-up) foram 13,5 dias (FU 1) e 19 meses (FU 2). Resultados: Os resultados radiológicos mostraram que a mobilidade geral da coluna lombar (L1 a S1) diminuiu, em média, um terço na amplitude de flexão e extensão, de 25, $0^{\circ}$ antes da cirurgia, para 17,6 $6^{\circ}$ depois. A mobilidade dos segmentos na estabilização monossegmentar diminuiu, em média, de 3,7 para 2,3․ Os segmentos caudais da estabilização dinâmica bissegmentar mantiveram a amplitude de movimento pré-cirúrgica de 2,6 $6^{\circ}$ chegando até $2,4^{\circ}$ depois da cirurgia. O IVS não foi alterado. O ODI melhorou depois da intervenção, de 59 para 39/41 (FU 1/FU 2) pontos, enquanto a VAS (durante movimento) melhorou de 7,6 (pré-operatório) para 4,4/4,5 (FU 1/FU 2). A análise auxiliada por computador mostrou que o pequeno e funcionalmente insignificante micromovimento de $0,4^{\circ}$ (erro de 0,12\%) permaneceu no segmento móvel estabilizado com técnica de não-fusão. Conclusão: A comparação das mensurações pré e pós-operatórias mostrou que a mobilidade geral e o micromovimento segmentar foram mantidos depois de estabilização da coluna lombar com técnica de não-fusão, com instrumentação mono e bissegmentar. O segmento rostral adjacente (IVS) não sofreu colapso. Os níveis de atividade (ODI) e os sintomas dolorosos (VAS) dos pacientes apresentaram melhora significante no acompanhamento, comparável aos relatados na literatura referentes às fusões espinais rígidas convencionais.

Descritores: Radiografia; Fixadores internos; Coluna vertebral; Parafusos ósseos.

1. MD, Zentrum für Rückenmarkverletzte und Klinik für Orthopädie - Halle, Germany.

2. MD, Medizinischen Klinik und Unfallchirurgie Lahr - Germany.

3. MD, BG Kliniken Bergmannstrost Klinik für Bildgebende Diagnostik und Interventionsradiologie - Halle, Germany.

The work was performed at: Zentrum für Klinik und für Orthopädie Rückenmarkverletzte Kliniken Berufsgenossenschaftliche Bergmannstrost Merseburger Straße 165 D - 06112 Halle / S., Germany. Corresponding :BG Kliniken Bergmannstrost. Zentrum für Rückenmarkverletzte und Klinik für Orthopädie Merseburger Str. 165, 06112 Halle, Germany.

E-mail: JoergRainer.Klauss@ bergmannstrost.com 


\section{RESUMEN}

Objetivo: Fue determinar in vivo si la movilidad preoperatoria de la espina lumbar (general y segmentaria) se mantiene después de la intervención quirúrgica. Métodos: La representación por imágenes de la espina lumbar se realizó en flexión y extensión, usándose una proyección lateral en condiciones estandarizadas. Esto permitió la evaluación de la movilidad general, la movilidad de los segmentos móviles instrumentados y la altura de disco del segmento craneano adyacente (espacio intervertebral; IVS), antes y después de la intervención quirúrgica. Las imágenes fueron evaluadas, independientemente, por un radiólogo y un cirujano ortopedista. Un análisis comparativo de las imágenes funcionales preoperatorias y posoperatorias fue realizado con la ayuda de una computadora y del software apropiado (ACES) para evaluación adicional de la extensión hasta la cual se mantuvo la amplitud del movimiento. El Índice de Incapacidad de Oswestry (ODI, evaluación de la calidad de vida) y la escala análoga visual (VAS, evaluación del dolor) fueron usados como criterios clínicos y comparados antes y después de la cirugía. Los intervalos promedio de seguimiento (FU) fueron 13,5 días (FU 1) y 19 meses (FU 2). Resultados: Los resultados radiológicos muestran que la movilidad general de la espina lumbar (L1 a S1) se redujo, en promedio, en un tercio de la amplitud de flexión/extensión, de 25,0ªntes de la cirugía a 17,6 después de la cirugía. La movilidad segmentaria, de la estabilización monosegmentaria, disminuyó, en promedio, de $3,7^{\circ}$ a 2,3 $3^{\circ}$ Los segmentos caudales de la estabilización dinámica bisegmentaria mantuvieron su amplitud de movimiento preoperatorio de $2,6^{\circ}$, con una extensión de $2,4^{\circ}$ después de la cirugía. El IVS no cambió. El ODI mejoró después de la cirugía de 59 (preoperatorio) puntos a 39/41 (FU1/FU2), mientras que la VAS (durante el movimiento) mejoró de 7,6 (preoperatoria) a 4,4/4,5 (FU1/FU2). El análisis, con ayuda de la computadora, mostró que un pequeño micromovimiento, funcionalmente insignificante, de 0,4 (error 0,12\%) permaneció en el segmento móvil estabilizado y no fusionado. Conclusión: La comparación de las mediciones preoperatoria y posoperatoria mostró que la movilidad general y el micromovimiento segmentario fueron mantenidos después de la estabilización no fusionada de la espina lumbar con instrumentación monosegmentaria y bisegmentaria. El segmento craneano adyacente (IVS) no tuvo un colapso. Los niveles de actividad (ODI) y los síntomas de dolor (VAS) de los pacientes mostraron mejoría significativa en el seguimiento, comparable a la que se informa en la literatura para fusiones espinales convencionales, rígidas.

\section{Descriptores: Radiografía; Fijadores internos; Columna vertebral; Tornillos óseos.}

\section{INTRODUCTION}

Surgical treatment of degenerative disease of the lumbar spine conventionally involves procedures for fixation and fusion of spinal motion segments. However, dynamic stabilisation with non-fusion systems is increasingly being used as an alternative procedure. With spinal fusion, the patient's pain is ultimately relieved at the cost of giving up whatever mobility he/she may still have had in the affected segment. This assumes that fusion and the consequent distribution of the residual mobility of the lumbar spine to the free segments is necessary. However, theoretical grounds and evidence from biomechanical in vitro studies ${ }^{1}$ suggest that non-fusion systems should make it possible to retain segmental mobility and distribution of mobility in the lumbar spine comparable with that prior to intervention. We therefore set out to determine clinically the extent to which segmental and overall mobility of the lumbar spine are retained after surgical treatment with a putative dynamic system. No in vivo studies have yet been published on a stabilising non-fusion internal fixator system with hinged screws. We wished to answer the following clinical questions: is the preoperative range of motion in the lumbar spine retained after surgery? Is there measurable residual mobility in the motion segment that has been instrumented but not rigidly stabilised? Can this residual mobility be used to deduce a change in the load distribution of the segment, independent of its clinical or functional utility? Based on theoretical considerations and the in vitro study of Schmoelz et al. ${ }^{1}$, this might suggest that fusion (whether ventral, posterolateral or $360^{\circ}$ ) is no longer necessary. This could reduce the invasiveness of the surgical procedure, and even prevent the occurrence of broken screws and arthropathy of adjacent vertebrae.

\section{MATERIALS AND METHODS}

In our study, a total of 38 patients underwent dynamic stabilisation of the lumbar spine with a pedicle screw-rod system between March 2004 and June 2007 which show images before surgery and 37 months after instrumentation of the L4/L5 segment in a 46 year-old man with post-discectomy syndrome). In contrast to other non-fusion pedicle screw systems, mobility in this system is not maintained by the longitudinal rod. The COSMIC screw (ulrich medical systems, UIm) that was used in this study has a flexible hinge joint that permits flexion and extension, but prevents translational or rotational movements. The system thus acts as a stabilising fixator, but still supports the buffering action of the intervertebral disc ${ }^{2}$.
All patients in the study gave informed consent to treatment and inclusion in the study. The radiology examinations were carried out after consultation with the relevant ethics committee; they were justified on medical grounds as follow-up investigations after surgical intervention to stabilise the vertebral column.

Inclusion criteria included degenerative changes in the lumbar spine from L1 to S1 over one, two, or (in three cases) three lumbar segments, with markedly reduced quality of life. Conservative treatment was exhausted in all patients and lumbar disease was clearly identified on the basis of imaging and clinical examination. X-ray images of the intervertebral space were used to exclude the possibility that spontaneous fusion had already taken place (Figure 1a-d).

Exclusion criteria included pathology of the lumbar spine in more than three segments, radiographic evidence of spontaneous fusion, motor deficits, inflammatory diseases of the spine, fractures or traumatic instabilities, pronounced scoliotic or sagittal deformities, as well as spondylolisthesis with a Meyerding grade of II or more.

A total of 16 women and 22 men were examined clinically, with an average age of $57( \pm 23)$ years. The first follow-up examination (T1) took place on discharge from hospital at an average of 13.5 days post-operatively. This involved collecting data for the Oswestry Disability Index (ODI, quality of life) and the Visual Analogue Scale (VAS, pain assessment). The second follow-up (T2) took place at an average of 19.4 months after surgery (range 3 to 37 months, standard deviation 8.4 months).

Indications for surgery were spinal stenosis (22 cases), post-discectomy syndrome (11 cases), instability (4 cases), spondylolisthesis (3 cases), facet degeneration (3 cases) and chronic or old intervertebral disc lesions (6 cases); multiple morbidities with these indications were also included. Indications included the whole range of degenerative diseases for which we use rigid fixation techniques. This was done in order to ensure better comparability of the clinical outcomes (VAS, ODI) with those reported in the literature for rigid instrumentation.

Investigations were carried out at all three time points (preoperative $=\mathrm{T} 0$, postoperative before discharge $=\mathrm{T} 1$, second follow-up $=$ T2). They involved clinical examination, imaging of the lumbar spine in two planes, as well as the Oswestry Disability Index (ODI) and VAS score. In 22 cases, lateral functional images of the lumbar spine of standing patients were taken at maximal flexion and extension, so that the range of movement could be compared at time points T0 and T2. Despite the standardised procedure, only 31 segments from 19 cases (86.4\%) could be evaluated with the FXA method ACES Ing. GmbH. Manual analysis of the functional radiographs was also carried out independently by a radiologist and an orthopaedic 


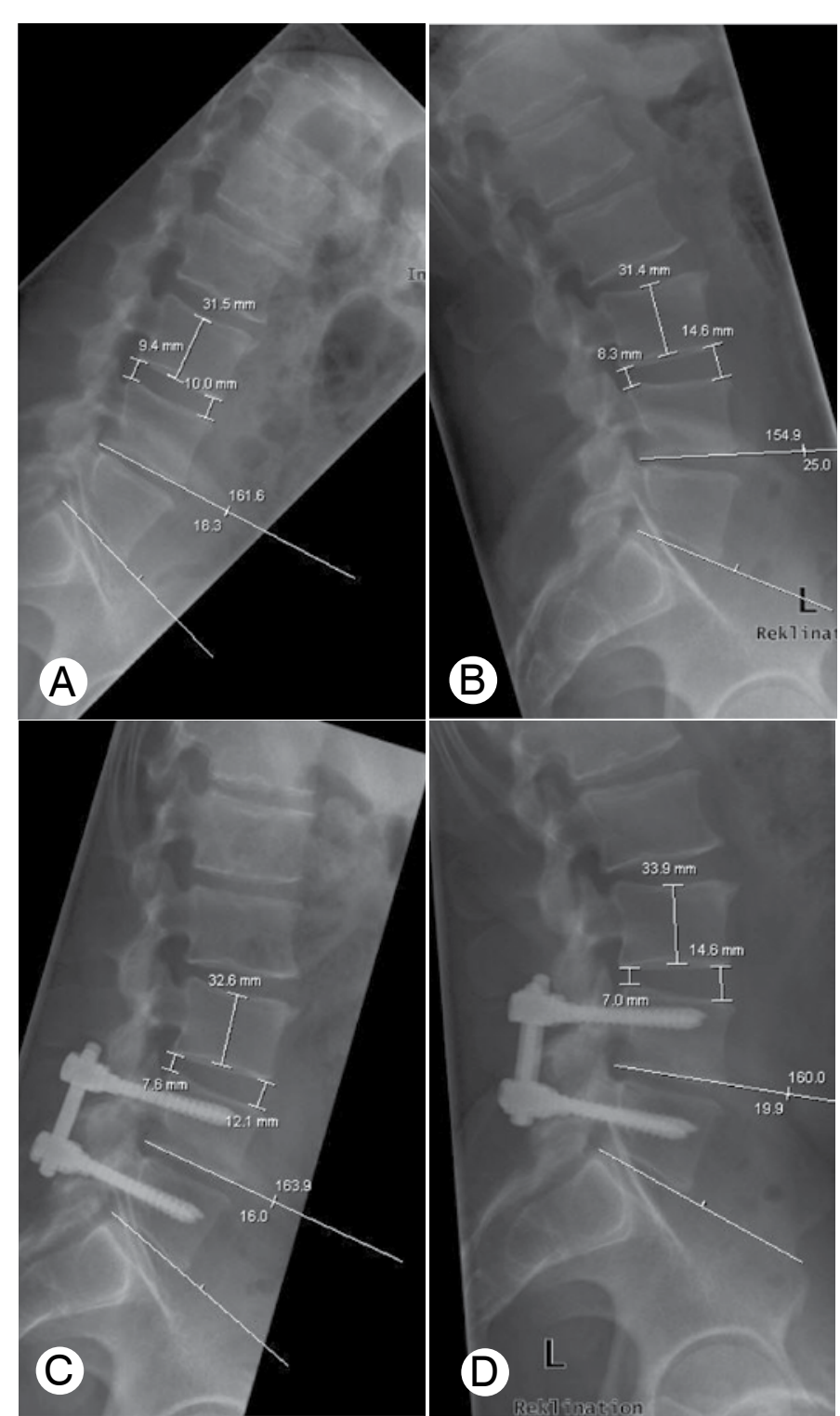

Figure 1A,B,C,D. Functional imaging of the lumbar spine, 46 y.o. male, post-discectomy syndrome L4/L5.

surgeon. Pre- and postoperative (T2) mobility (ROM) were determined, including evaluation of individual segments. Degeneration of adjacent vertebrae was also evaluated, with tests for instability and assessment of any pathology due to the instrumentation. The analysis of mobility included measurement of the sagittal Cobb angle of the whole lumbar spine (in flexion and extension) between the inferior endplate of $\mathrm{L} 1$ and the superior endplate of S1, measurement of the sagittal Cobb angle for individual stabilised segments from superior endplate to superior endplate, and measurement of the intervertebral space (IVS, disc height) in the adjacent cranial segment (Figure 2). The Cobb angle was measured between superior endplates (S1 having no inferior endplate) in order to exclude differences in the measurements due to variability in divergence of the vertebral bodies.

The surgical interventions were carried out under standardised conditions by four experienced surgeons, each of whom had performed over 300 posterior instrumentations of the lumbar spine. The lumbar spine was exposed in the prone patient using posterior midline access and monitoring with image intensification. Instrumentation was applied to the relevant pedicles using a convergent posterolateral approach. Additional decompression of the spinal canal, and/or foraminotomy or undercutting decompression were performed if necessary.

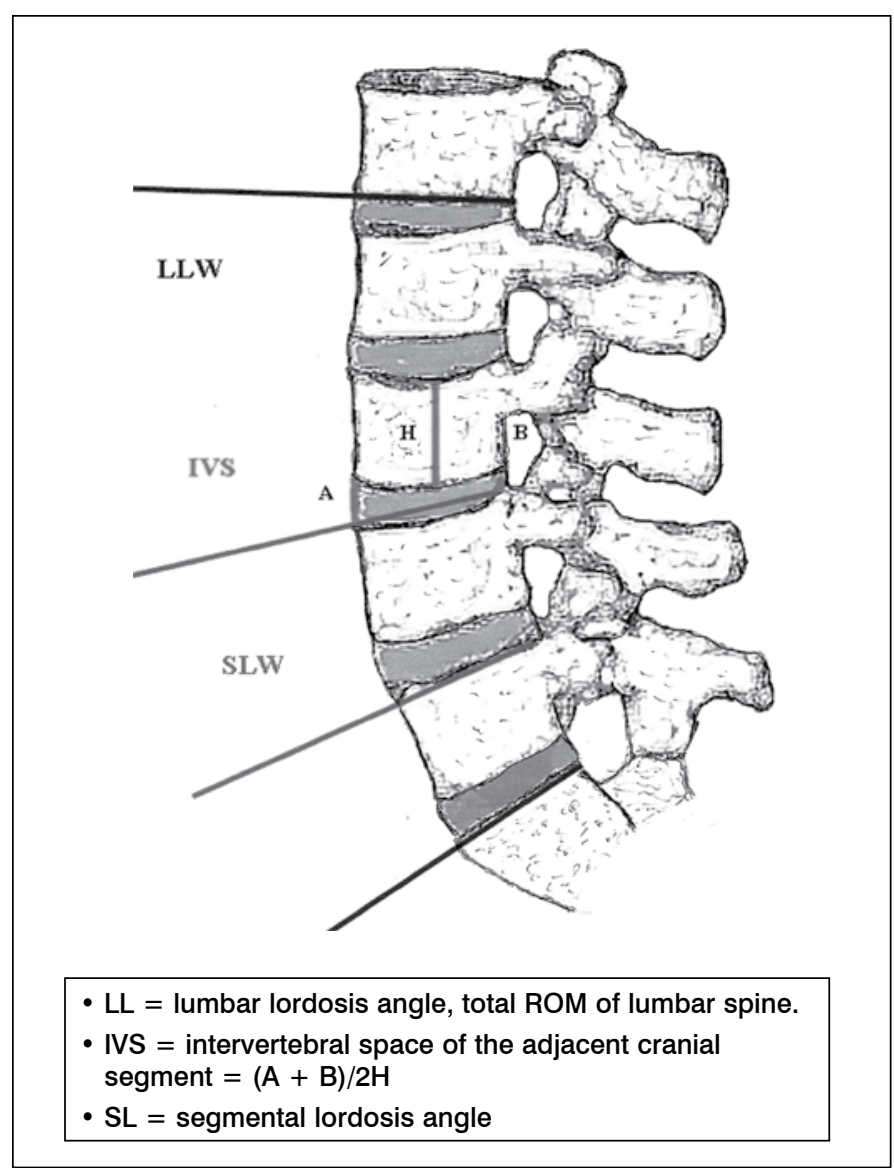

Figure 2. Radiological parameters, ascertained in flexion and extension.

\section{RESULTS}

This study involved spinal stabilisations of which 19 (50.00\%) were monosegmental, 16 (42.11\%) bisegmental and $3(7.89 \%)$ trisegmental. One bisegmental stabilisation of L2-L4 (2.63\%) was performed immediately cranial to an existing spinal fusion at L4-S1.

The average hospital stay was 13.5 days. It was specified as 14 days prior to surgery to allow better physiotherapy care in hospital. However, in some cases the patient insisted on early discharge and did not stay this long. Good outpatient physiotherapy therefore compensated for a shorter postoperative stay.

During the follow-up period, no degeneration of adjacent vertebrae was found on clinical examination or with imaging techniques.

Loosening of one instrumentation (2.63\%) was found in the follow-up period after a three-segment stabilisation on an obese patient. Revision surgery was used to convert the stabilisation to a spinal fusion. Other dislocations or material failures did not occur during the follow-up period. Two patients did not appear for follow-up, so that only 35 patients could be followed up with conventional radiology and clinical examination.

The mobility studies in which radiographs were compared by radiologists and orthopaedic surgeons had an inter-observer variability with a measurement error of $6.4 \%$. In detail, the results are as follows:

Mobility studies of the lumbar spine after posterior dynamic stabilisation found no significant change in the overall mobility of the lumbar spine in the monosegmental subgroup, and mobility of the stabilised segment was retained. The range of movement of the lumbar spine was $25.0^{\circ}$ prior to surgery and $17.2^{\circ}$ after surgery.

The segmental mobility (ROM) was measured for the cranial and caudal segments of each operated region. The ROM of the cranial stabilised segment (the only segment in monosegmental stabilisations) was $3.7^{\circ}$ prior to surgery and $2.3^{\circ}$ afterwards, while in the 
segment caudal to this (the intermediate segment of the trisegmental stabilisations) it was $2.6^{\circ}$ before surgery and $2.4^{\circ}$ afterwards. For the caudal segment of the two trisegmental stabilisations, it was $0^{\circ}$ before surgery and $-1^{\circ}$ afterwards (Figure 3 ).

The Oswestry and VAS scores were significantly improved after surgery in the study cohort. These results are comparable with data in the literature for fusion of the lumbar spine. The Oswestry score improved from 59 (preoperative) to 39 (T1) and 41 (T2). Similarly, the VAS score at rest / moving was reduced from 6.1 / 7.6 (T0) to $3.1 / 4.4$ (T1) and 3.4 / 4.5 (T2) (Figures 4 and 5).

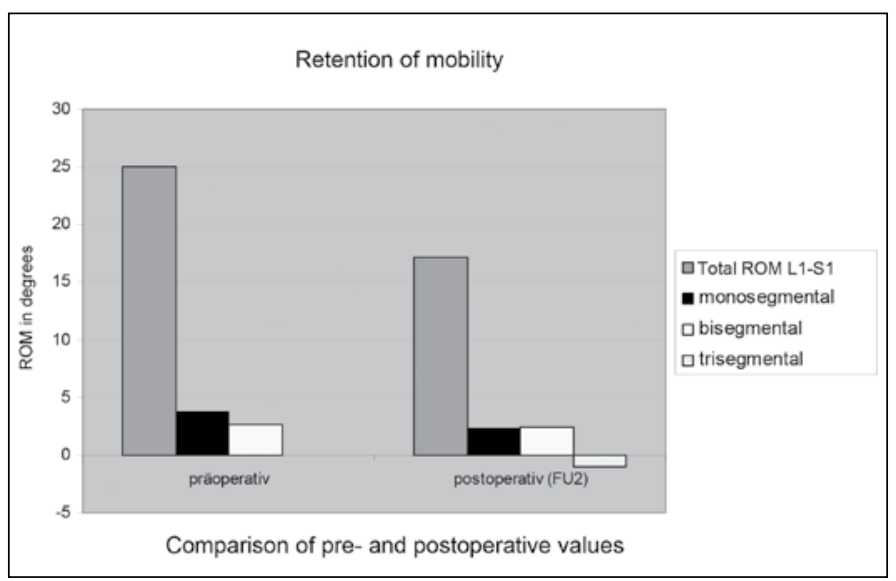

Figure 3. Mobility of the lumbar spine - Manual analysis.

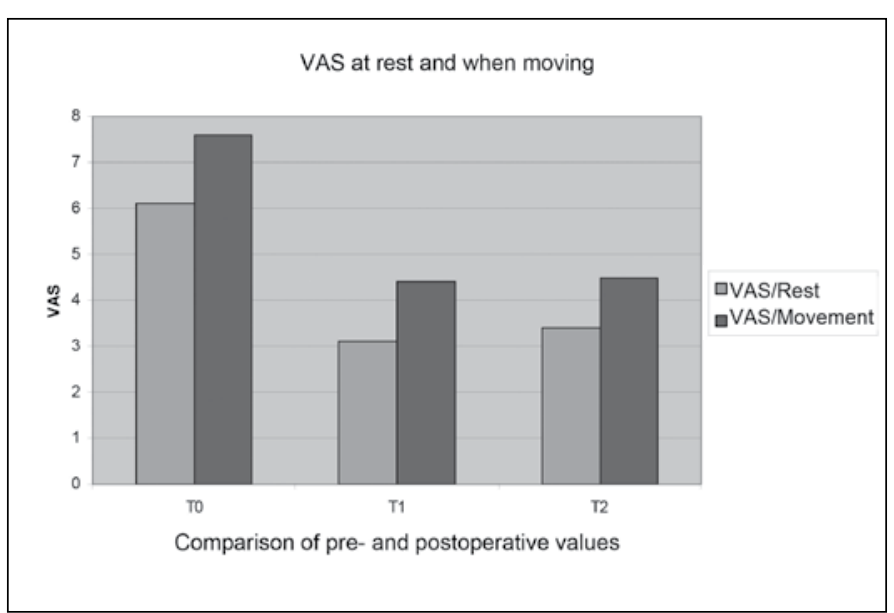

Figure 4. VAS - preoperative and postoperative comparison.

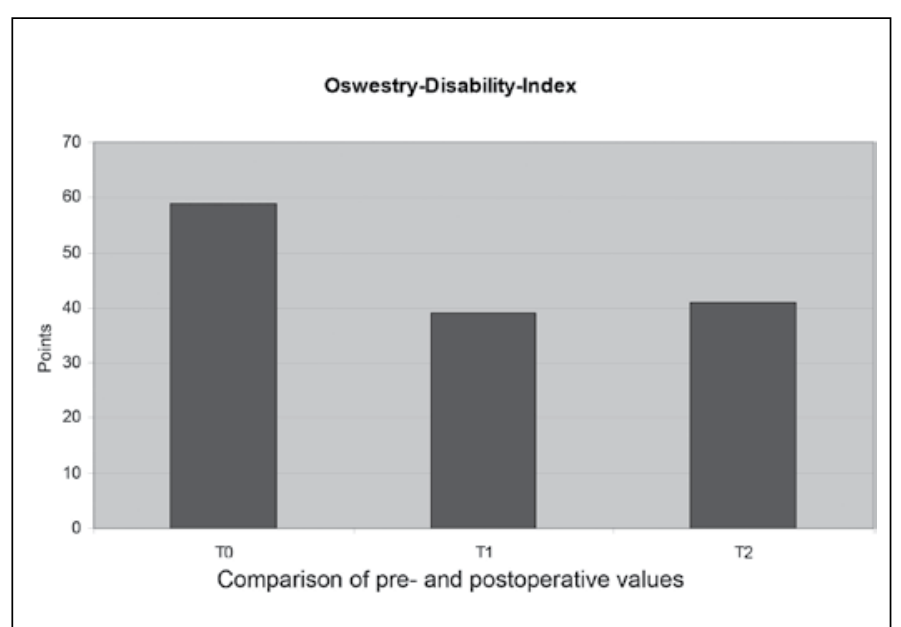

Figure 5. ODI - preoperative and postoperative comparison.
Tests of inter-observer variability between the radiologists and the orthopaedic surgeons showed a good correlation in their evaluations of the functional images. The correlation amounted to an average of 0.8 with an error probability of $6.4 \%$. The determination of segment mobility was almost identical for the two groups of observers; larger deviations were observed only in determining the total ROM of the lumbar spine.

Tests using the FX analysis software (ACES Ing. GmbH) found an error probability of $0.12 \%$.

Detailed results are as follows. Pre- and post-operative functional images were available for 22 operated patients (9 monosegmental, 8 bisegmental and 2 trisegmental); 19 of these patients were evaluated. This involved assessment of a total of 31 instrumented segments ( 9 monosegmental, 16 bisegmental and 6 trisegmental). There was a reduction in the total ROM of the lumbar spine (L1-S1) from $22.8^{\circ}$ (min. $4.6^{\circ}$, max. $55.9^{\circ}$ ) prior to surgery to $14.6^{\circ}$ after surgery, but it was not significant $(p=0.085)$ (Figura 6). However, the segmental mobility of the mono-and bisegmental instrumentations decreased significantly $(p<0.05)$ from $3.4^{\circ}$ pre-operatively (min. $-0.1^{\circ}$, max. $9.1^{\circ}$ ) to $0.4^{\circ}$ postoperatively (min. $0.0^{\circ}$, max. $5.4^{\circ}$ ). With an error magnitude of $0.12 \%$, this still indicates retention of micro-motion in the instrumented segment of greater than zero within the standard deviation. The computer-assisted measurements indicate that the segmental mobilities of the trisegmental instrumentations were retained to about the same extent when pre-and postoperative results were compared. However, a definite statement is not justified given the limited data (2 patients, 6 segments).

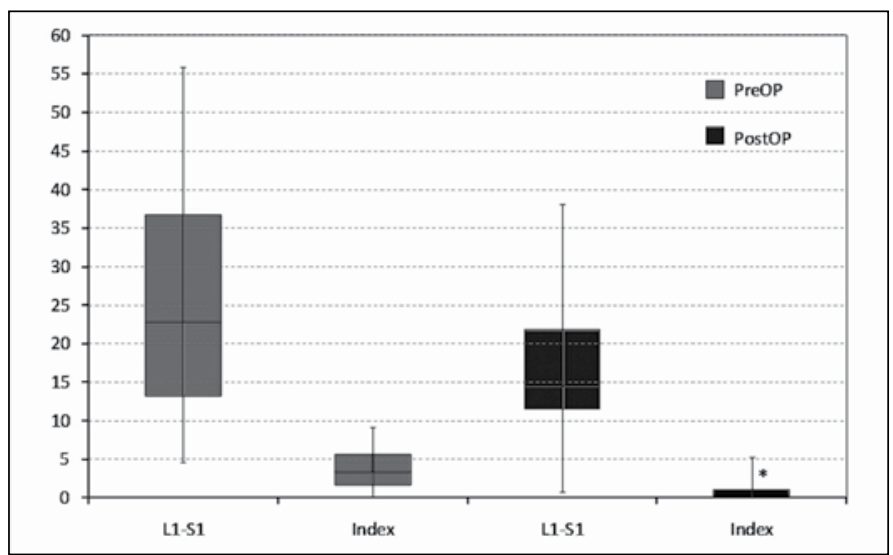

Figure 6. Mobility of the lumbar spine - FXA.

\section{DISCUSSION}

Functional imaging is commonly used in clinical practice to assess the range of motion of the lumbar spine.

This method has often been criticised because of its large varian$\mathrm{ce}^{3-5}$, which is regarded as due to differences in patient compliance and the criteria used by investigators. In our study, precise definition of the reference points for the manual measurements resulted in excellent inter-rater reliability. Comparison with computer-based analysis (FXA, ACES-Ing. $\mathrm{GmbH}$ ) demonstrated the superiority of FX analysis (error probability $0.12 \%$ to $6.4 \%$ ). This appears to be more useful for scientific purposes, although for regular clinical use the conventional standardised method seems quite satisfactory.

This study has allowed us to provide what we believe is the first clinical evidence on postoperative retention of sagittal mobility after non-fusion stabilisation with the system used by us.

The overall lumbar range of motion was retained with monosegmental and bisegmental instrumentation. Some micro-motion was retained in individual segments, but this minimal residual mobility is unlikely to be functionally significant. In our view, the benefit of this micro-mobility is primarily in load redistribution, so that instrumentation without fusion appears to be justified. The stability 
achieved is close to what could only be attained otherwise by rigid spinal fusion. We also regard additional decompression of the spinal canal as feasible with procedures such as extended bilateral interlaminar fenestration (up to and including laminectomy), without concerns about overloading the system. However, specific comparative follow-up studies are still needed on non-fusion instrumentation of spinal stenosis with decompression, as against stabilisation by rigid fusion.

According to the literature, our patients had a smaller range of movement, before and after surgery, than the normal population ${ }^{6,7}$. Normal values in the literature for in vivo segmental mobility of the lumbar spine are between $11^{\circ}$ and $14^{\circ}$ for flexion and extension. Our preoperative ROMs were already clearly diminished by morbidity, with values of $3^{\circ}-6^{\circ}\left(3.5^{\circ} \pm 2.9^{\circ}\right)$. Postoperatively, the segmental $\mathrm{ROM}$ measurements were significantly reduced to $0.4^{\circ}$. However, the minimal retained segmental mobility was also confirmed postoperatively for the system we used for mono- and bisegmental indications, with maximum stability but without rigidity.

\section{IVS (Intervertebral space)}

A clear assessment of adjacent degenerative changes by assessing the IVS could not be made due to the number of cases and the duration of follow-up. Deterioration of the IVS was not seen in any of the cases in the cohort study, so that an obvious collapse of the adjacent cranial segment was not found in the patients we investigated. We can therefore report that such adjacent degeneration was not found, at least for the follow-up period (FU2). However, a series of long-term prospective in vivo studies is still needed to demonstrate the efficacy of the dynamic instrumentation we used in preventing "adjacent level disease", since the only relevant experiments were done in vitro ${ }^{8}$.

\section{Symptom relief}

The Oswestry and VAS scores showed a significant reduction of lumbar symptoms, both immediately after surgery and during the follow-up period. The results are consistent with the reference literature for both rigid and dynamic stabilisation ${ }^{9-12}$.

\section{Incidence of complications}

The time taken for surgery, low level of trauma caused by the intervention, use of stored blood and length of hospital stay were all consistent with reports in the literature for rigid stabilisation ${ }^{9-12}$. During the follow-up period, only one material displacement occurred with a trisegmental instrumentation and a dural leak at left $L 4$, with subsequent paresis of the ankle dorsiflexors and pre-existing hypoaesthesia in left $L 4$ and $L 5$ dermatomes in the same patient. This was a case of trisegmental stenosis of the spinal canal from L2 to L5, with comorbid type 2 diabetes, obesity, and postmenopausal osteoporosis.
Material failures such as breakage or displacement of a screw or rod were not found. These results suggest that the incidence of complications is comparable with that for other systems.

\section{Limitations}

The number of patients with trisegmental instrumentation (3 patients, one of whom required revision to spinal fusion) was too small to permit meaningful conclusions

The restriction of movement that was already found prior to surgery was related to existing pathology and the technique of functional imaging with the patient standing. This technique was standardised in order to detect instability and vertebral slippage under the influence of gravity, as opposed to other standard methods (functional imaging with the patient sitting or lying on his side). A greater range of movement is therefore conceivable, both pre- and postoperatively. However, the in vitro studies should be noted here ${ }^{1,2,8}$

The range of degenerative diseases of the lumbar spine that were indications for surgical intervention in this study had a deliberate bias. This did not affect the in vivo comparison of function, but it did influence the clinical criteria of the VAS and ODI data. A correlation between clinical and radiological parameters would therefore not be valid.

\section{CONCLUSION}

This study is the first to provide in vivo data on the segmental mobility retained after instrumentation with a dynamic pedicle screw system. This relatively small mobility was documented with pre-and postoperative functional imaging of the lumbar spine in flexion and extension. All preoperative and postoperative functional images were assessed independently by an orthopaedic surgeon and a radiologist according to predetermined criteria. The assessments showed a high level of agreement with a small error size. Use of a computer-based analysis system increased the reliability of results further. Especially posterior monosegmental and bisegmental instrumentation of the lumbar spine with this system tended to reduce the total range of motion of the lumbar spine, but the reduction was not significant. Some mobility was retained at the segmental level, although it was minimal in extent. This suggests that loads are redistributed by the fixation system to the intervertebral disc spaces. The clinical data reported here are consistent with those reported in the literature for rigid systems with a similar significant improvement in the Oswestry Disability Index and VAS scores. Given the absence of instrumentation-related complications, stabilisation with this non-fusion system can be regarded as satisfactory and appropriate for good clinical outcomes.

\section{REFERENCES}

1. Fritz JM, Piva SR, Childs JD. Accuracy of the clinical examination to predict radiographic instability of the lumbar spine. Eur Spine J. 2005;14(8):743-50.

2. MöllerTB. [X-ray Findings in the Normal Population]. Stuttgart: Georg Thieme Verlag; 2003.

3. Okawa A, Shinomiya K, Komori H, Muneta T, Arai Y, Nakai O. Dynamic motion study of the whole lumbar spine by videofluoroscopy. Spine (Phila Pa 1976). 1998;23(16):1743-9.

4. Ozer AF, Crawford NR, Sasani M, Oktenoglu T, Bozkus H, Kaner T, et al. Dynamic lumbar pedicle screw-rod stabilization: two-year follow-up and comparison with fusion. Open Orthop J. 2010;4:137-41.

5. Penning L, Wilmink JT, van Woerden $\mathrm{HH}$. Inability to prove instability. A critical appraisal of clinical-radiological flexion-extension studies in lumbar disc degeneration. Diagn Imaging Clin Med. 1984;53(4):186-92.

6. Schmoelz W, Huber JF, Nydegger T, Dipl-Ing, Claes L, Wilke HJ. Dynamic stabilization of the lumbar spine and its effects on adjacent segments: an in vitro experiment. J Spinal Disord Tech. 2003;16(4):418-23.

7. SchmoelzW, Huber JF, Nydegger T, Claes L, Wilke HJ. Influence of a dynamic stabilisation

system on load bearing of a bridged disc: an in vitro study of intradiscal pressure. Eur Spine J. 2006;15(8):1276-85.

8. Schmoelz W, Onder U, Martin A, von Strempel A. Non-fusion instrumentation of the lumbar spine with a hinged pedicle screw rod system: an in vitro experiment. Eur Spine J. 2009;18(10):1478-85

9. Stoffel M, Behr M, Reinke A, Stüer C, Ringel F, Meyer B. Pedicle screw-based dynamic stabilization of the thoracolumbar spine with the Cosmic-system: a prospective observation. Acta Neurochir (Wien). 2010;152(5):835-43

10. Stokes IA, Frymoyer JW. Segmental motion and instability. Spine (Phila Pa 1976). 1987:12(7):688-91.

11. von Strempel A, Moosmann D, Stoss C, Martin A. Stabilisation of the degenerated lumbar spine in the non fusion technique with Cosmic posterior dynamic system. WSJ. 2006;(1):40-7.

12. Maleci A, Sambale RD, Schiavone M, Lamp F, Özer F, von Strempel A. Nonfusion stabilization of the degenerative lumbar spine. J Neurosurg Spine. 2011;15(2):151-8. 